DOI: $10.15290 /$ bsl.2021.18.10

\author{
Aleksandra Dąbrowska \\ Wydział Polonistyki \\ Uniwersytet Warszawski \\ e-mail: a.dabrowska62@student.uw.edu.pl \\ ORCID: 0000-0002-0957-6052
}

\title{
Gatunek - postać - widzenie. Poetyka Arfa Macieja Szukiewicza
}

Twórczość Macieja Szukiewicza, sytuująca się na peryferiach literatury powstającej w okresie Młodej Polski, odzwierciedla prądy, tendencje i techniki, które pojawiły się w literaturze na przełomie XIX i XX wieku. Dzięki lekturom, studiom i swoim licznym podróżom Szukiewicz zdołał zaznajomić się bowiem $z$ najnowszymi zjawiskami kultury europejskiej ${ }^{1}$. Po powrocie z czeskiej uczelni brał czynny udział w życiu artystycznym Krakowa. Jeszcze w czasach studiów na Wydziale Filozoficznym Uniwersytetu Jagiellońskiego dołączył do grona "cyganerii”, z której wywodziło się wielu wybitnych dramaturgów Młodej Polski. Publikował w czasopismach recenzje z wystaw i spektakli, prace krytyczne oraz notatki o zjawiskach związanych z kulturą czeską. Autor Arfa prowadził także działalność translatorską i edytorską, a ponadto interesował się technicznymi aspektami teatru i sceny. Rozległe doświadczenie oraz gruntowna wiedza Szukiewicza zaowocowały powstaniem kilkunastu dramatów osadzonych w konwencji realistycznej i baśniowej. Arf ${ }^{2}$ należy do tej drugiej grupy utworów.

\footnotetext{
1 Informacje na temat biografii Macieja Szukiewicza za: A. Podstawka, Dramaturgia Macieja Szukiewicza, Lublin 2006, s. 15-74.

2 Dramat po raz pierwszy został opublikowany w 1902 r. na łamach „Przeglądu Polskiego”. W tym samym roku ukazała się jego publikacja w formie książkowej. Utwór nigdy nie został wystawiony na scenie.
} 
Chociaż przez dziesięciolecia Szczukiewicz pozostawał w cieniu wielkich nazwisk i nie sposób porównywać go z najwybitniejszymi artystami epoki, to właśnie na przykładzie jego dramatu można prześledzić, w jaki sposób rama dramatyczna i wzorce genologiczne wpływają na percepcję zdarzeń przez odbiorców. Rzeczywistość przedstawiona w Arfie jawi się jako skomplikowana konstrukcja tekstowa, oscylująca między baśnią a misterium. Obydwa wzorce genologiczne stanowią soczewki interpretacyjne nałożone na trzecią płaszczyznę uniwersum dramatu, czyli na płaszczyznę zdarzeń realistycznych. Autor zastosował szereg rozmaitych rozwiązań formalnych regulujących relacje pomiędzy tymi płaszczyznami. Analiza budowy ramy dramatycznej i genologicznego ukształtowania utworu pozwoli określić charakter tych relacji i odsłonić głębsze warstwy semantyczne tekstu.

\section{W świecie baśni i misterium}

Baśniowy status świata przedstawionego w dramacie Szukiewicza został ustalony na wielu poziomach, począwszy od chronotopu, a na schemacie fabularnym skończywszy. Topografia terenu ukazanego w Arfie jest typowo baśniowa: leśna polana, chatka wiedźmy, ruiny zamku. Usytuowanie akcji $\mathrm{w}$ tak konwencjonalnych, a zarazem tak odrealnionych lokalizacjach, ma umożliwić wpisanie zdarzeń $\mathrm{w}$ perspektywę uniwersalną. $\mathrm{W}$ ten sposób dramat właściwie przeistacza się $\mathrm{w}$ przypowieść o charakterze ponadlokalnym i ponadjednostkowym, zawierającą określony projekt antropologiczny. Konwencjonalność symboli zastosowanych w dramacie ewokuje perspektywę uniwersalną, lecz zarazem stanowi konsekwencję posługiwania się konkretem w sferze obrazowania. W didaskaliach bardzo dokładnie określono bowiem czas i miejsce wydarzeń, doprecyzowano najmniejsze szczegóły scenerii silnie osadzone $\mathrm{w}$ wyobrażeniach ludowych. Zdawałoby się, że wobec wcześniej postawionej tezy o uniwersalności, operowanie konkretem wprowadza w obręb utworu pewien rodzaj sprzeczności czy też antynomii. Baśń należy jednak do gatunków, które owo przeciwstawienie czynią główną zasadą konstrukcyjną. Jak zauważa Magda Nabiałek:

Analizie baśni dramatycznej towarzyszyć musi świadomość nieustannego napięcia między wysokim i niskim, dwuperspektywiczności wykorzystywanej tradycji ujawniającej się niejednokrotnie $\mathrm{w}$ jednym utworze $\mathrm{z}$ jednoczesną świadomością ciążenia jej z jednej strony ku uschematyzowanemu oglądowi świata, z drugiej - ku widzeniu "czystemu", niezapośredniczonemu, gwarantującemu ogląd świata w jego pierwotnym kształcie ${ }^{3}$.

3 M. Nabiałek, Baśń dramatyczna - zapomniane ogniwo, "Zagadnienia Rodzajów Literackich" 2019 , t. 62 , z. 3, s. 116 . 
Potencjał baśni tkwi zatem właśnie w dualistycznym aspekcie obrazowania. Co istotne, dzięki sięgnięciu po rezerwuar elementów zakorzenionych w tradycji ludowej, możliwość odczytania wydarzeń z pierwszych scen dramatu w perspektywie metafizycznej została znacznie ograniczona. Część badaczy sygnalizowała, że baśń jest mitem zdegradowanym, odartym z dawnych treści sakralnych, inni zaś twierdzili, że to baśń jest pierwotniejsza od mitu Obie tezy wskazują, że projekt makrokosmosu baśni nie zakłada poszerzenia świata w kierunku wertykalnym. Jest to gatunek zorientowany na sferę profanum czy też na sferę materii. W odniesieniu do Arfa teza ta zyskuje potwierdzenie w słowach samego autora: „Element ten [element zła - A.D.] jako pojęcie oderwane reprezentuje w dramacie Rokita; konkretnem, a zarazem szczegółowem złem jest Wiedźma; oboje zaś odpowiednikami krępującej ducha materii" 5 .

Poetyka baśniowa uwidacznia się w Arfie także w przebiegach fabularnych. Wiele zdarzeń ukazanych na scenie można wpisać w schemat bajki magicznej skonstruowany przez Władimira Proppa ${ }^{6}$. Sytuacja wyjściowa w dramacie wiąże się z doświadczeniem braku. Ludzie utracili szczęście wskutek działań zła, więc oczekują teraz na swojego wybawcę, który wskaże im drogę do krainy jasności. Arf, jako oczekiwany wybawiciel, jest wręcz modelowym typem bohatera poszukiwacza. Wyrusza na wędrówkę, by odnaleźć drogę do Jasnej Ziemi, a osiągnięcie tego celu wymaga odszukania królewny pogrążonej w głębokim śnie. Protagonista posługuje się także czarodziejskim środkiem - złotą lutnią.

W przypadku literatury równie ważne jak wzorzec bywają jednak poczynione od niego odstępstwa. Tych w utworze Szukiewicza nie brakuje. Autor Arfa naruszył (zdaniem Proppa niezmienne) następstwo funkcji, ponieważ bohater otrzymał złotą lutnię jeszcze przed rozpoczęciem scenicznego dziania się. Co więcej, donatorem jest główna postać z kręgu zła. Dwie, zdawałoby się, antynomiczne role zostały ze sobą $\mathrm{w}$ tym utworze skontaminowane. Zawarte w tekście zniekształcenia baśniowej topiki stanowią konsekwencję zastosowania $\mathrm{w}$ dramacie określonej ramy dramatycznej i pojawienia się drugiego wzorca gatunkowego, czyli misterium.

W Arfie zastosowano wiele elementów charakterystycznych dla poetyki misteryjnej. Elementy te uwidaczniają się jednak nie tyle na poziomie bu-

\footnotetext{
${ }^{4} \mathrm{O}$ różnych koncepcjach związanych ze wzajemnym stosunkiem mitu i baśni wspominała w swojej publikacji A. Czabanowska-Wróbel. Zob. A. Czabanowska-Wróbel, Baśń w literaturze Młodej Polski, Kraków 1996, s. 12-15.

5 M. Szukiewicz, Arf. Poemat w 4 aktach, „Przegląd Polski” 1902, t. 145, s. 211.

6 W. Propp, Morfologia bajki, przeł. S. Balbus, „Pamiętnik Literacki” 1968, z. 4, s. 203-242.
} 
dowy formalnej, co raczej na poziomie treści. W tym przypadku gatunek implikowany jest przede wszystkim za sprawą działań samej postaci. To bohater staje się nośnikiem określonego wzorca genologicznego stanowiącego odzwierciedlenie jego światopoglądu. Już w początkowych replikach Arf podkreśla odmienność swojego statusu ontologicznego:

Wybacz jeżelim zamącił twą ciszę
Świeckim pogwarem i przyjimij przybłędę
Ze świata ludzi, choć nie z tego świata -
Bo idąc ziemią na błękitach wiszę ${ }^{7}$.

Perspektywę dotarcia do transcendencji Arf zarysowuje także za pomocą poetyckich porównań. W jednym z monologów przyrównuje się chociażby do kwiatu chłonącego nieskończoność, który rozbłysnął przyozdobiony w liliową koronę. Innym razem snuje rozważania na temat siły własnej myśli, której nadaje nieomal sakralny charakter, ponieważ „przychodzi na świat jak Hosanna" [A, s. 53].

Działania głównego bohatera, aż do końca III aktu, można interpretować w kluczu biblijnym. Kilkuletnia tułaczka Arfa po pustkowiach przywodzi na myśl wędrówkę Mojżesza, który miał doprowadzić lud do Ziemi Obiecanej. Przywódca Izraelitów otrzymał Arkę Przymierza mającą zapewnić im zwycięstwo. W ręce Arfa trafiła natomiast złota lutnia stanowiąca klucz do Jasnej Ziemi, w której czeka wieczna szczęśliwość. Mojżesz musiał mierzyć się z szemrzącym ludem. Bohaterowi dramatu Szukiewicza także przyszło stanąć oko w oko z Wątpcem siejącym bunt w obozie. Obok figury Arfa-Mojżesza w dramacie występuje także figura Arfa-Chrystusa. Gdy Wiedźma w przebraniu pustelnika prosi o kroplę krwi, której rzekomo potrzebuje do stworzenia eliksiru nieśmiertelności, to właśnie Arf okalecza swoją dłoń. Nasuwają się tu skojarzenia związane z odkupieńczą misją Chrystusa. Konfrontację Arfa z Wątpcem, który zabiera głównego bohatera nad przepaść, można przyrównać do próby kuszenia Syna Bożego na wzgórzu. Arf upomina członków starszyzny, by nie poddawali się zwątpieniu i czuwali. Chrystus zwracał się do apostołów w podobnych słowach tuż przed swoją męką.

Misteryjna perspektywa działań głównego bohatera uwidacznia się $\mathrm{w}$ wielu replikach, gestach i autokomentarzach. To on najczęściej tematyzuje wątek wtajemniczenia i ofiary, cierpienia i wybawienia. Jego perspektywa

\footnotetext{
7 M. Szukiewicz, Arf, Kraków 1902, s. 25. Kolejne cytaty lokalizuję, posługując się symbolem A.
} 
nie jest jednak perspektywą dominującą w dramacie. Sposób, w jaki Szukiewicz kontaminuje obydwa gatunki, sprawia bowiem, że potencjał misterium zostaje ograniczony, a nawet zdekonstruowany przy pomocy zastosowanej ramy dramatycznej.

\section{Projekt ramy dramatycznej}

Małgorzata Sugiera podkreśla, że rama $\mathrm{w}$ dramacie ściśle powiązana jest $\mathrm{z}$ kategorią widzenia ${ }^{8}$. W tekście Szukiewicza wyraźnie uwidacznia się ten percepcyjny aspekt ramy, która stanowi składnik świata przedstawionego, a zarazem determinuje sposób oglądu zdarzeń i odpowiada za określenie modalności utworu. Zasadniczy element ramy dramatycznej znajduje się w początkowych partiach Arfa. Autor w pierwszej scenie dramatu nie oddaje głosu protagoniście, lecz postaciom wywodzącym się z kręgu zła. Najważniejszą z nich jest Rokita. Uwagę zwraca przeprowadzony przez niego eksperyment dotyczący istoty cierpienia. Diabeł przykłada mrówkę do najcieńszej błonki chrząszcza łączącej głowę z kadłubem, a potem spogląda na starcie owadów, zwracając się do większego z nich:
[...] Będziesz miotał się rozpacznie,
Ona nie da się oderwać,
Nie da się odpędzić więcej,
Bowiem głodna jest i mądra
I bezczelna nad pojęcie.
Dla niej cały twój majestat
Nie istnieje. Chciwa żeru
Powyjada ci wnętrzności.

$$
\text { [A, s. 6-7] }
$$

Słowa te można interpretować w kontekście losów Arfa. Niebawem Wiedźma uderzy przecież w najczulszy punkt bohatera, tworząc Miłotę, która odwiedzie go od wypełnienia powierzonej mu misji. Eksperyment zyska zatem większą skalę, a jego antycypowany wynik przesądzi o kształcie nakreślonego w utworze projektu antropologicznego.

Działania Rokity mają istotny wpływ na sens wydarzeń rozgrywających się na scenie. Diabeł łączy w sobie funkcję donatora i przeciwnika.To on dopuścił do tego, by złota lutnia trafiła w ręce ludzi. Jego wypowiedź zdradza, że było to działanie celowe:

\footnotetext{
8 M. Sugiera, Zapośredniczone spojrzenie: ramy i punkty widzenia w dramacie, w: Elementy dramatu. Analizy diagnostyczne, red. M. Sugiera, M. Borowski, Kraków 2009, s. 142.
} 
Poruszyłem płatek śniegu,

Co w lawinę wnet się zmieni

I już pora iść mi w gąszcze

I przyglądać się igrzysku.

$$
\text { [A, s. 12] }
$$

Słowa o zorganizowanym przez niego widowisku implikują przeistoczenie świata przedstawionego w theatrum mundi, którego prawodawcą jest właśnie szatan. $\mathrm{W}$ ten sposób diabeł zdobywa uprzywilejowaną pozycję $\mathrm{w}$ dramacie. Odgrywa bowiem rolę inscenizatora, a zarazem obserwatora zmagań Wiedźmy i ludzi. Cała akcja utworu jawi się zatem jako domena działania zła, w której człowiek zostaje sprowadzony do pozycji marionetki w rękach szatańskich sił.

Eksperyment Rokity i mnożenie jego ról sprawiają, że to właśnie nakreślona przez niego perspektywa oglądu zdarzeń staje się perspektywą dominującą, którą w konsekwencji przyjmuje także widz/czytelnik. Rozpoznanie to znajduje swe potwierdzenie w specyfice replik Rokity, w których przeważa impresywna funkcja języka. Szatan kieruje uwagę interlokutora na konkretne obrazy i elementy przestrzeni, co czyni za sprawą sformułowanych przez siebie poleceń i pytań: "pilnie wpatrz się w bór”; "Teraz pilnie patrz i słuchaj”; „Słyszysz jak się odzew niesie? Słyszysz?”; „Widzisz? widzisz?”. Konsekwencją tego zabiegu jest wyznaczenie diabłu kolejnej funkcji w świecie przestawionym, czyli pozycji operatora ${ }^{9}$, do którego zadań należy modulowanie spojrzenia widza. Za sprawą dwukierunkowości słowa dramatycznego przytoczone pytania i rozkaźniki, mimo iż skierowane do Wiedźmy, można odczytywać także jako wskazówki dla widowni, która dzięki nim poznaje historię związaną z odnalezieniem złotego instrumentu.

Uczynienie z diabła medium informującego pozwala przypuszczać, że dysponuje on pełną wiedzą na temat tego, co dzieje się w całym uniwersum dramatu, zarówno $\mathrm{w}$ perspektywie mikro- jak i makrokosmosu scenicznego. Rokita posiada zatem więcej informacji niż pozostali bohaterowie i w związku z tym może wykorzystać ich niewiedzę. Wobec tych rozpoznań przestaje dziwić, zasygnalizowane wcześniej, połączenie funkcji donatora i przeciwnika. Rokita doskonale zna najczulszy punkt Arfa, wie, że ludzie z powodu swoich słabości nie będą w stanie uczynić z lutni żadnego pożytku. Obdarowuje ich magicznym środkiem tylko po to, by zainscenizować swoje widowisko i uczynić ich los igraszką w swoich rękach.

\footnotetext{
9 Pojęciem tym posługuję się za Magdą Nabiałek. Zob. M. Nabiałek, Scena - między słowem a obrazem. O kompozycji dramatów Juliusza Słowackiego, Kraków 2018, s. 31.
} 
Po przygotowaniu widowiska Rokita przechodzi na pozycję obserwatora zdarzeń, a jego kreacyjna funkcja zostaje przedłużona za sprawą działań Wiedźmy. Według rozpoznań Proppa na jeden krąg akcji w baśni może przypadać kilka postaci ${ }^{10}$. Właśnie tak dzieje się w utworze Szukiewicza. Wiedźma zastępuje diabła w roli inscenizatora. Najpełniej objawia się to $\mathrm{w}$ III akcie dramatu, kiedy zleca swoim pomocnikom przeistoczenie ruin zamku w dostojną budowlę. Te działania przypominają aranżowanie sceny teatralnej, na której za moment rozegra się zainscenizowany przez nią spektakl. Wiedźma tworzy także główną aktorkę tego spektaklu - Miłotę, a potem instruuje ją, w jaki sposób ma postępować, by zwieść Arfa. Po zaaranżowaniu sceny sama zajmuje zaś pozycję widza. Od tego momentu schemat baśni, zdominowany przez zło, ponownie staje się główną soczewką oglądu zdarzeń.

Rama dramatu, którą nakreślają diabeł i Wiedźma, determinuje interpretację scenicznego dziania się, a przede wszystkim ma fundamentalny wpływ na postrzeganie przez odbiorcę głównego bohatera. Sprawia, że punkt widzenia protagonisty zostaje przełamany. Działania Arfa przestają być bowiem percypowane jako dokonujące się właśnie wielkie wyzwolenie ludu i przeistaczają się $\mathrm{w}$ proces powolnego wpadania $\mathrm{w}$ zastawioną na bohatera pułapkę. Kiedy Wiedźma w przebraniu pustelnika podsyca w bohaterze jego próżność, ogłaszając go wodzem, ten bezkrytycznie przyjmuje zaprojektowaną przez nią wizję. Od tej pory postać Arfa zaczyna ciążyć ku wzorcowi bohatera misteryjnego. Najistotniejszy w kontekście zagadnienia związanego z percepcją świata przedstawionego jest jednak fakt, że główny bohater właściwie przestaje dokonywać racjonalnego samooglądu. Podsumowanie postawy przyjętej przez Arfa mogą stanowić słowa Marci Sá Cavalcante Schuback, która zauważa: „nauczyliśmy się, że człowiek uwodzony przez nieskończone idee musi koniecznie zapomnieć o rzeczach skończonych" ${ }^{11}$. W dalszej części artykułu autorka zastrzega, że spojrzenie „musi przywiązać się do rzeczy, by nie zatracić się całkiem w otwartym horyzoncie"12. Arf postąpił w odwrotny sposób. Zatracił zdolność racjonalnej oceny własnych sił, stracił z pola widzenia granicę oddzielającą rzeczywistość od ułudy zaprojektowanej przez siły zła.

\footnotetext{
10 Zob. W. Propp, Morfologia bajki, s. 219.

11 M. Schuback, Odyseusz przy maszcie, w: tejże, Pochwała nicości. Eseje o hermeneutyce filozoficznej, przeł. L. Neuger, Kraków 2008, s. 106.

12 Tamże, s. 107.
} 
Nakreślony przez Szukiewicza projekt sceniczny nie stanowi jego autorskiego pomysłu. Zastosowane przez niego rozwiązania konstrukcyjne mają swoje odpowiedniki w dramatach Juliusza Słowackiego. Goplana w Balladynie i Bukary w Samuelu Zborowskim, podobnie jak Rokita, wcielają się w podwójne role. Kreują, a zarazem oglądają wydarzenia rozgrywające się na scenie, balansując pomiędzy funkcjami inscenizatorów a widzów ${ }^{13}$. Najwięcej analogii, zarówno pod względem konstrukcji, jaki treści, można jednak odnaleźć pomiędzy Arfem a Kordianem. W dramacie Słowackiego na początku scena także zostaje zdominowana przez postaci z kręgu zła, których działanie wyznacza ramy scenicznego dziania się, determinując zarazem sposób oglądu zdarzeń. Magda Nabiałek tak pisze o roli Przygotowania w perspektywie całego dramatu:

Jeżeli potraktować Przygotowanie jako instrukcję jednego z możliwych sposobów czytania historii Kordiana, to instrukcja ta wskazywać będzie nie tylko najistotniejsze dla dzieła tematy, lecz także będzie odsłaniać kompozycję samego tekstu ${ }^{14}$.

Szatan u Słowackiego również jest kreatorem zdarzeń, kształtującym mikrokosmos sceniczny według własnych upodobań. W jego wypowiedziach został stematyzowany proces widzenia rzeczywistości, co przyczynia się do narzucenia określonego modelu percepcji, którego główny bohater nie będzie W stanie przekroczyć ${ }^{15}$.

Podobieństw jest jeszcze więcej. Stwarzanie przywódców powstania na początku dramatu Słowackiego stanowi realizację projektu obdarowania ludzkości środkiem służącym do jej wyzwolenia. Środek ów, zarówno u Słowackiego, jak i u Szukiewicza, ma okazać się bezużyteczny, zwodniczy. Siły zła dają ludzkości nadzieję na realizację marzeń o wolności tylko po to, by ludzie mogli zderzyć się z własną niemocą. To właśnie niemożność spełnienia czynu, implikowana przez działania zła, stanie się zamiennikiem antycznego fatum, rządzącego losami jednostek i całych społeczności.

13 Zob. M. Nabiałek, Scena - między słowem a obrazem. O kompozycji dramatów Juliusza Słowackiego, s. 129-130, 261-266.

14 Tamże, s. 53.

15 Zob. Tamże, s. 51-52. 


\section{Obnażyć rzeczywistość}

Rama nakreślona przez Rokitę stale determinuje sposób oglądu zdarzeń, niekiedy jednak jej funkcja ekspansywności zostaje ograniczona. Gdy postaci z kręgu zła nie pojawiają się na scenie bezpośrednio, milcząca obecność sił szatańskich sygnalizowana jest w inny sposób, chociażby za sprawą didaskaliów, w których wspomniano o złowieszczych dźwiękach puchacza ${ }^{16}$ czy też o krwawej barwie nieba. Niepokój związany z przeczuwaniem czyjejś obecności formułują w bezpośrednich wypowiedziach również niektóre postacie ${ }^{17}$. Usunięcie bohaterów z kręgu zła poza obręb scenicznego dziania się i zasygnalizowanie ich wpływu na przebieg wydarzeń w nieco mniej wyraźny sposób pozwala zogniskować uwagę widza na innym aspekcie fabuły. W niektórych scenach to napięcie pomiędzy misterium a płaszczyzną widzenia racjonalistycznego staje się bowiem główną osią dialogu. Wzajemne krzyżowanie spojrzeń postaci pochodzących ze wskazanych płaszczyzn świata przedstawionego wprowadza nowy aspekt tematyczny dramatu, ukazujący relacje pomiędzy Arfem a jego poddanymi.

O ile Arf nie jest w stanie przeniknąć wzrokiem płaszczyzny działania zła, o tyle może dość precyzyjnie formułować diagnozy dotyczące postawy podległego mu ludu. Podczas pierwszego spotkania z drużynami Arf tak wyraża się o społeczeństwie:

O ludzie dobrzy ale małej wiary,

Serca płonące lichym ogniem słomy!

Zbawienia chcecie, nie chcecie ofiary!

Ochotni wtedy, kiedy cel widomy

Waszych zabiegów, gdy go macie w dłoni.

Cóżby ci rzekli, co tak długie wieki

Z cierniowym wieńcem wygnańców na skroni,

Jak świat ten cały wielki i daleki

Szli i szli błądząc bez iskry nadziei.

[A, s. 37]

\footnotetext{
16 Wzmianki, które padają w dramacie na temat tego zwierzęcia związane są z kategorią widzenia: „ARF: Dobregoś sobie wybrał towarzysza!/Dziwny ptak. Okiem oczy jego chwytam / Podobne słońcu, w którego blask wierzę! / Jaka w tych oczach roztropność i cisza, / Jak one ciągną mnie, jak one nęcą / Wciąż bardziej, silniej..." [A, s. 27]. Wcześniej to Wiedźma poleciła puchaczowi, by ten uważnie przyglądał się wydarzeniom:„WIEDŹMA: A ty oczy zmruż, lecz patrzaj" [A, s. 19].

17 „ZNÓJ: Choć sie wto i w ziemie schowa / I tam jesce sam nie będzie. / Zawdy wtoś cy coś jes przy nas" [A, s. 47].
} 
Lud nie pozostaje mu jednak dłużny. Osoby z tłumu także dokonują oceny głównego bohatera. Wytykają mu patos, wywyższanie się, jednocześnie podkreślając, że wódz i starszyzna nie potrafią racjonalnie spojrzeć na rzeczywistość:

SIÓDMY Z TŁUMU

Cicho, cicho, spojrzcie na nich

Jak się prężą, nasłuchują.

[...]

SZÓSTY Z TŁUMU

Oto czem się oni trudnią,

Nasłuchują szumu wichrów,

A na ziemi jęk wciąż głusi.

[A, s. 62]

Arf staje zatem przed trudnym zadaniem przekonania społeczeństwa o konieczności podjęcia wysiłku związanego z dążeniem do wyzwolenia. Przeciwnikiem, który chce pokrzyżować jego zamiar, jest tym razem nie diabeł, a Wątpiec. Jeżeli część postaci dramatu potraktować jako projekcje wewnętrznych stanów psychiki bohaterów, co jest zgodne z zasadami modernistycznego dramatu analitycznego ${ }^{18}$, to należy stwierdzić, że Wątpiec reprezentuje nastawienie części społeczeństwa, która podaje w wątpliwość słuszność wizji ich wodza. Arf toczy zatem walkę na dwóch frontach: $\mathrm{z}$ własną słabością wyzyskiwaną przez siły zła oraz ze zwątpieniem, któremu poddaje się prowadzony przez niego lud.

Działanie głównego bohatera, wpisujące się we wzorzec misterium, stanowi probierz nastrojów społecznych. Arf obnaża słabość ludu, niegotowość do podjęcia ofiary, a także niemożność pełnej konsolidacji społeczeństwa.

\section{Anagnorisis}

Mateusz Borowski zwracał uwagę, że głównym zadaniem bohatera $\mathrm{w}$ dramacie tradycyjnym było zdobycie informacji o swojej tożsamości, o swoim przeznaczeniu ${ }^{19}$. W przypadku Arfa proces osiągnięcia samopoznania dokonuje się na końcu aktu III, kiedy to bohater dopuścił już do zniszczenia złotego instrumentu.

\footnotetext{
18 Zob. J. Waligóra, Młodopolski „dramat wewnętrzny”, Kraków 2004, s. 85-130.

19 Zob. M. Borowski, Tożsamość miejsca. Modele konstrukcji przestrzeni w dramacie, w: Elementy dramatu. Analizy diagnostyczne, s. 148.
} 
Moment samopoznania został przedstawiony w dramacie za pomocą tak chętnie wykorzystywanej w okresie modernizmu, konwencji onirycznej. Podczas gdy Arf zapada w głęboki sen u boku Miłoty, na scenie pojawiają się widma i cienie stanowiące alegoryczne przedstawienia wewnętrznych głosów protagonisty, projekcję jego sumienia. Konstrukcja tej sceny także znajduje swój odpowiednik w dramaturgii Słowackiego, a konkretnie w replikach Strachu i Imaginacji ${ }^{20}$. W dramacie Szukiewicza alegoryczne projekcje wewnętrznych głosów bohatera, tak jak w przypadku Kordiana, wyznaczają punkty, na których ma zogniskować się spojrzenie protagonisty, niejako zmuszając go do skonfrontowania się z rzeczywistością. Cienie ukazują bowiem obrazy o znaczeniu symbolicznym: tryskające krwią serce i krzyż. Przy tym nieustannie napominają bohatera: „Arfie, słysz!”; „Słyszysz stuk?”; „Widzisz? Patrz!"; "Spojrzeć racz!”. Tłum zjaw, tak jak Rokita i Wątpiec, posiada zdolność manipulowania spojrzeniem odbiorców, wyznaczania punktów, na których ma skupiać się wzrok interlokutorów, a w konsekwencji także spojrzenie odbiorcy zewnątrztekstowego.

Zjawy dręczą śpiącego, oskarżają o zdradę i sprzeniewierzenie się narodowej sprawie. Wypominają $\mathrm{mu}$, że nawoływał ludzi do ofiarności, sam zaś nie był w stanie wyrzec się jednej chwili rozkoszy. Szczególne znaczenie w onirycznym „sądzie sumienia" ma zestawienie postawy Arfa z cierpieniem Chrystusa. Dzięki temu bohater może skonfrontować swoje niedopełnione misterium z prawdziwą ofiarą odkupieńczą:

\section{DZIEWIĄTY CIEŃ \\ Czy poznajesz kto tam kona? \\ $\mathrm{W}$ imię twoje światem biegł, \\ Był jak płomień, był jak śnieg. \\ $\mathrm{W}$ imię twoje naprzód rwał \\ W walkę się z ciemnością wdał, \\ Czynił, co ty jeno śnisz - \\ Za to jemu teraz krzyż!}

$$
\text { [A, s. 109] }
$$

Słowa o śnieniu ukazują misteryjną perspektywę Arfa jako ułudę. Po ocknięciu się ze snu bohater zauważa wreszcie, że jego dotychczasowa kreacja była kreacją fałszywą, co wyraża w następujących słowach:

20 Zob. M. Nabiałek, Scena - między słowem a obrazem. O kompozycji dramatów Juliusza Stowackiego, s. 60 . 


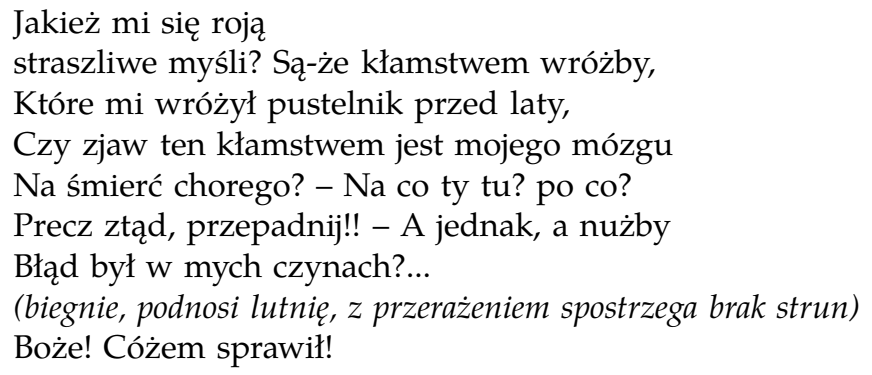

[A, s. 113]

W tym momencie główny bohater po raz pierwszy zauważa skutki działań postaci z płaszczyzny fantastycznej. Arf uświadamia sobie, iż stał się igraszką sił zła, które zaprojektowały baśniowy świat ułudy. Świadomość tragizmu własnego losu związana jest zatem z poczuciem obnażenia swojej słabości, odarcia ze złudzeń. To kluczowy punkt dramatu, co potwierdza trafność tezy Thomasa Stearnsa Eliota, że „rzeczywiście świetna retoryka pojawia się $w$ momentach krytycznych, kiedy bohaterowie sztuki sami siebie widzą w dramatycznym świetle" ${ }^{21}$. W ostatniej scenie aktu Arf prezentuje właśnie takie widzenie. Po raz pierwszy od spotkania z Wiedźmą kieruje spojrzenie na samego siebie i dostrzega dwoistość natury ludzkiej: rozerwanie pomiędzy transcendencją a materią, pomiędzy dążeniem ku wielkości a własną słabością, pomiędzy ideą a realnością.

Co istotne, samo rozpoznanie dokonało się dopiero, gdy główny bohater został skonfrontowany z wizją Chrystusa Ukrzyżowanego oraz z wizją bolejącej matki. Prawdziwa autorefleksja protagonisty wymagała zatem odpowiedniego punktu odniesienia, skierowania spojrzenia na osobę trzecią, a zatem przejścia na pozycję widza. W tym aspekcie również można byłoby przyrównać Arfa do Kordiana, który w szpitalu wariatów został skonfrontowany z dwoma obłąkanymi i dopiero wówczas mógł uprzytomnić sobie naśladowczy charakter swoich działań ${ }^{22}$. Tę regułę można odnieść nie tylko do postaci dramatu, lecz także do odbiorcy zewnątrztekstowego. Spojrzenie na bohatera, który dokonuje anagnorisis, skłania czytelnika do podobnego działania. Postać literacka sama staje się punktem odniesienia, z którym można skonfrontować własną postawę. Taki schemat procesu rozpoznania zyskuje swe wyjaśnienie w teorii hermeneutycznej: „Dlatego jest zawsze tak, że gdy

21 T.S. Eliot, "Retoryka” i dramat poetycki, w: tegoż, Szkice krytyczne, przeł. M. Niemojowska, Warszawa 1972, s. 190.

22 Zob. M. Nabiałek, Scena - między słowem a obrazem. O kompozycji dramatów Juliusza Słowackiego, s. 78. 
widzi się po platońsku »jedno«, widzi się zawsze dwa, widzi się rzecz i horyzont $^{\prime 23}$. Za sprawą przemieszczania postaci na pozycję obserwatora po raz kolejny objawiła się zasada, że punkt widzenia pełni $\mathrm{w}$ dramacie istotną funkcję i przesądza o sposobie interpretacji zdarzeń.

\section{Na przecięciu światów}

W ostatnim akcie dramatu akcja przenosi się na wieś polską. Dochodzi zatem do odwrócenia proporcji $\mathrm{w}$ świecie przedstawionym. Teraz to płaszczyzna zdarzeń realistycznych wypełnia całą przestrzeń, niemniej jej kształt zdeterminowany jest przez wydarzenia, które nastąpiły w płaszczyźnie baśniowo-misteryjnej. Struny złotego instrumentu są już bowiem zerwane, na ziemi zapanowała pożoga.

Kwestia skoku Arfa, który dokonał się na końcu poprzedniego aktu, ma kluczowe znaczenie w perspektywie interpretacji zakończenia dramatu. Rozpaczliwy czyn protagonisty doprowadził do uratowania lutni, dając także nadzieję na odzyskanie wolności. Wyraźną zapowiedź dotarcia do Jasnej Ziemi stanowią słowa Znoja i Arfa skierowane do dziecka ${ }^{24}$, któremu przekazano instrument:

ZNÓJ

[...] To se weźmies to do ręki,

Skróś mogiłek bedzies nosił,

Bo i z nich duch wielgi idzie

Budujący i posilny.

ARF

A wtedy wstąpią w nią znów siły nowe,

Ogromne, wieczne

I znów się znajdą struny piorunowe

I drogi mleczne,

Drogi gwiazdami usiane złotemi.

I pójdą, wejdą do Jasnej Ziemi

Narody świata.

[A, s. 141]

Według tezy Proppa przekazanie magicznego środka może stanowić jedno z pozytywnych rozwiązań historii ${ }^{25}$. Mogłoby się zatem wydawać, że właśnie

23 M. Schuback, Odyseusz przy maszcie, s. 107.

24 Arf także otrzymał lutnię jako dziecko. Opowieść wraca zatem do punktu wyjścia.

25 Zob. W. Propp, Morfologia bajki, s. 222. 
takie zakończenie ma miejsce w przypadku dramatu Szukiewicza. Tuż po słowach wypowiedzianych przez Arfa rozlega się jednak złowieszczy śmiech Rokity, co stanowi wyraźną zapowiedź tego, że plany następcy bohatera także zostaną pokrzyżowane. Prawa baśni są bowiem prawami odwiecznymi, a u Szukiewicza ustanawia je zło symbolizujące materię. Baśniowa rama zaprojektowana przez Rokitę sprawia, że historia świata może być interpretowana $\mathrm{w}$ kontekście cyklicznie powtarzających się porywów ducha i następujących po nich klęsk. Baśniowe koło historii jest $\mathrm{w}$ gruncie rzeczy błędnym kołem.

Śmiech Rokity implikuje wystąpienie w dramacie motywu dziejowego zapętlenia, lecz umożliwia zarazem ogólnospołeczne rozpoznanie. Wraz ze śmiechem diabła do świata wydarzeń realistycznych przenika baśń. Zebrani wokół ludzie słyszą złowieszcze dźwięki i dzięki temu po raz pierwszy uświadamiają sobie dramatyzm swojego położenia wynikający z podlegania prawom wyznaczonym przez niewidoczne, lecz stale obecne siły. Wyraża to chóralny okrzyk całej społeczności: „Popadliśmy w moc złego!” [A, s. 142]. Anagnorisis nabiera teraz wymiaru społecznego i dokonuje się dzięki uświadomieniu sobie istnienia sfery określającej ramy funkcjonowania w świecie. Przekroczenie granic ludzkiego poznania $\mathrm{w}$ dramacie Szukiewicza nie polega zatem na wkraczaniu w świat idei, lecz na rozpoznaniu własnego położenia, które realizację owej idei uniemożliwia. Paradoksalnie to właśnie dopiero zrozumienie własnej słabości, którą wyzyskuje zło, doprowadza do zetknięcia się $\mathrm{z}$ transcendencją. $\mathrm{W}$ ostatniej scenie na prośbę ludu $\mathrm{z}$ przydrożnego krucyfiksu rozchodzi się bowiem strumień światła, zapowiadający interwencję Chrystusa w dzieje świata. Prawdziwe misterium wyzwolenia przychodzi zatem z zewnątrz.

Michaił Bachtin stwierdził, że gatunki literackie należy traktować jako światopoglądy, implikujące określony sposób patrzenia na rzeczywistość przedstawioną ${ }^{26}$. Stwierdzenie badacza dosknale uwidacznia się właśnie w takich utworach, jak dramat Szukiewicza. W Arfie zarówno baśń, jak i misterium implikują odmienny schemat interpretacyjny, którego nośnikami są wybrani bohaterowie. Baśń odpowiada za nakreślenie praw rządzących światem przedstawionym na poziomie profanum, a zatem na poziomie materii. Misterium ukazuje natomiast świat wielkiej Idei i poszerza mikrokosmos sceniczny o sferę sacrum. W ten sposób powstaje spójny projekt makrokosmosu teatralnego. Kontaminacja genologiczna sprawia, że z jednej strony gatunki implikują wykorzystanie gotowych wzorców strukturalnych i interpretacyj-

26 Zob. M. Bachtin, Problem gatunków mowy, w: tegoż, Estetyka twórczości słownej, przeł. D. Ulicka, Warszawa 1986, s. 348-402. 
nych, z drugiej zaś stają się nośnikiem treści, które się w tych wzorcach nie mieszczą. Dramat Szukiewicza stanowi także dowód na siłę ramy dramatycznej. Oddając baśń we władanie postaci z kręgu zła, autor w zasadzie przekształca scenę $\mathrm{w}$ theatrum mundi, w którym człowiek staje się marionetką w rękach wrogich mu sił. Baśniowa rama zakreślona przez Rokitę jest tak mocna, że nie może zostać przekroczona od wewnątrz, dlatego właśnie na końcu dramatu autor sięga po misterium Chrystusa, który reprezentuje najwyższy, transcendentny porządek.

\section{Bibliografia}

Bachtin Michaił (1986), Problem gatunków mowy, w: M. Bachtin, Estetyka twórczości słownej, przeł. D. Ulicka, Warszawa: Państwowy Instytut Wydawniczy, s. 348-402.

Borowski Mateusz (2009), Tożsamość miejsca. Modele konstrukcji przestrzeni w dramacie, w: Elementy dramatu. Analizy diagnostyczne, red. M. Sugiera, M. Borowski, Kraków: Księgarnia Akademicka, s. 145-162.

Czabanowska-Wróbel Anna (1996), Baśń w literaturze Młodej Polski, Kraków: Universitas.

Eliot Thomas Stearns (1972), „Retoryka” i dramat poetycki, w: T.S. Eliot, Szkice krytyczne, przeł. M. Niemojowska, Warszawa: Państwowy Instytut Wydawniczy, s. $187-194$.

Nabiałek Magda (2018), Scena - między słowem a obrazem. O kompozycji dramatów Juliusza Słowackiego, Kraków: Universitas.

Nabiałek Magda (2019), Baśń dramatyczna - zapomniane ogniwo, „Zagadnienia Rodzajów Literackich", t. 62, z. 3, s. 103-119.

Podstawka Anna (2006), Dramaturgia Macieja Szukiewicza, Lublin: Towarzystwo Naukowe Katolickiego Uniwersytetu Lubelskiego Jana Pawła II.

Schuback Marcia Sá Cavalcante (2008), Odyseusz przy maszcie, w: M. Schuback, Pochwała nicości. Eseje o hermeneutyce filozoficznej, przeł. L. Neuger, Kraków: Wydawnictwo Uniwersytetu Jagiellońskiego.

Sinko Tadeusz (1918), Świat baśni, „Maski”, z. 7-8, s. 127-131, 148-152.

Sławińska Irena (2003), Główne problemy struktury dramatu, w: Problemy teorii dramatu i teatru, wybór i oprac. J. Degler, Wrocław: Wydawnictwo Uniwersytetu Wrocławskiego, s. 84-101.

Sugiera Małgorzata (2009), Zapośredniczone spojrzenie: ramy i punkty widzenia w dramacie, w: Elementy dramatu. Analizy diagnostyczne, red. M. Sugiera, M. Borowski, Kraków: Księgarnia Akademicka, s. 119-143.

Szukiewicz Maciej (1902), Arf, Kraków: Czas.

Świontek Sławomir (2003), O strukturalnych zwiazkach i zależnościach tworzyw dzieła dramatycznego, w: Problemy teorii dramatu i teatru, wybór i oprac. J. Degler, Wrocław: Wydawnictwo Uniwersytetu Wrocławskiego, s. 110-118. 
Truskolaska Anna (1983), Młodopolska ekspansja pojęcia „misterium”, w: Wśród mitów teatralnych Młodej Polski, red. I. Sławińska, M.B. Stykowa, Kraków: Wydawnictwo Literackie, s. 277-305.

Waligóra Jerzy (2004), Młodopolski „dramat wewnętrzny”: przejawy podmiotowości i subiektywizacji w wybranych utworach dramatycznych, Kraków: Wydawnictwo Naukowe Akademii Pedagogicznej.

\title{
Genre-Character-Seeing. The Poetics of Arf by Maciej Szukiewicz
}

\begin{abstract}
The article analyzes Arf, a drama by Maciej Szukiewicz and one of the least known pieces from the period of Young Poland. The author demonstrates that the world presented results from a complex textual form that oscillates between a fairy tale and a mystery play. These two genological forms constitute an interpretative lens through which the world of real events in the drama is read. The author uses Szukiewicz to illustrate how the framework of drama and the generic patterns bear upon the way in which the readers perceive the storyline.
\end{abstract}

Keywords: genre, point of view, fairy tale, character, scenic framework 